\title{
Effect of serum from tilapia Oreochromis aureus immunized with the dinospore Amyloodinium ocellatum on the motility, infectivity and growth of the parasite in cell culture
}

\author{
S. A. Smith ${ }^{1, *}$, E. J. $\operatorname{Noga}^{1}{ }^{,}$M. G. Levy ${ }^{2}$, T. M. Gerig ${ }^{3}$ \\ ${ }^{1}$ Department of Companion Animal and Special Species Medicine \\ ${ }^{2}$ Department of Microbiology, Pathology and Parasitology, College of Veterinary Medicine \\ ${ }^{3}$ Department of Statistics, College of Physical and Mathematical Sciences, North Carolina State University, Raleigh, \\ North Carolina 27606, USA
}

\begin{abstract}
Serum from the tilapine fish Oreochromis aureus immunized intraperitoneally with Amyloodinium ocellatum dinospores stimulated an immune response that was detectable by enzymelinked immunosorbeut assay (ELISA), cell culture infectivity, and motility assays. A response was detected as early as $3 \mathrm{wk}$ in both the ELISA and infectivity assay with immune serum inhibiting the infectivity and growth of the parasite in cell culture. Parasite infectivity in cell culture was inversely related to serum antibody ELISA titers. Fresh serum had a greater inhibitory effect than heat-inactivated serum. Live parasites induced a greater immune response than did dead, sonicated parasites as determined by both the ELISA and the infectivity assay. Serum from fish immunized with live parasites immobilized the infective dinospores at serum concentrations of $5 \%$ and greater by $5 \mathrm{~min}$, as well as in lower serum concentrations at longer time intervals. Parasite agglutination occurred in immune serum concentrations from 2.5 to $0.156 \%$.
\end{abstract}

\section{INTRODUCTION}

Amyloodinium (Oodinium) ocellatum is one of the most important and globally ubiquitous protozoan pathogens of both wild and cultured marine fish (Sindermann 1990), with most warmwater estuarine and marine fish being susceptible (Lawler 1979). The organism has caused epidemics in aquarium and feral fish (Brown 1931, 1934, Nigrelli 1936, 1940, Dempster 1955, Laird 1956), cultured pompano (Lawler 1977a), striped bass (Lawler 1980), sea bass (Ghittino et al. 1980, Paperna 1980), sea bream (Paperna 1980) and red drum (Lawler 1980).

The protozoan has a triphasic life cycle (Brown 1931,

\footnotetext{
- Addressee for correspondence; present address: Department of Pathobiology, Virginia-Maryland Regional College of Veterinary Medicine, Virginia Polytechnic Institute and State University, Blacksburg, Virginia 24061, USA
}

1934, Brown \& Hovasse 1946, Nigrelli 1936) which includes a parasitic, feeding trophozoite stage (trophont) attached by thin rhizoids to epithelial cells of the host. After maturation, the trophont detaches from the host and transforms into an encysted, dividing stage (tomont). Subsequent mitotic divisions produce a large number of tomonts which excyst, resulting in an equivalent number of free-swimming infective stages (dinospores). These can infect the same or a different host where the life cycle may be repeated in only $6 \mathrm{~d}$ under optimum host and environmental conditions.

Despite the importance of Amyloodinium ocellatum, relatively little is known of the protective mechanisms by which host fish may resist infection. Fish may acquire resistance following sublethal exposure to $A$. ocellatum (Paperna 1980, Lawler 1977b, 1980). Thus, potential exists for the development of a vaccine. The purpose of this study was to characterize the immune response of fish immunized with antigens of the dino- 
spore stage of $A$. ocellatum and determine the kinetics of the response. In addition, the various assays were compared for their utility in characterizing the fish's immune response.

\section{MATERIALS AND METHODS}

Experimental animals and maintenance. Adult blue tilapia Oreochromis aureus from stock maintained by the Department of Zoology, North Carolina State University, Raleigh (USA), were maintained in freshwater and acclimated for 2 wk before immunization. Water quality (ammonia, nitrite and $\mathrm{pH}$ ) was monitored bi-weekly, and temperatures were checked daily. For Expt 1,6 tish ( 3 per group) were held individually at $25^{\circ} \mathrm{C}$ and 0 ppt salinity in $110 \mathrm{l}$ aquaria, partitioned by perforated plexiglass into 3 equal compartments. Water quality was maintained by box filters of crushed coral and fish were fed an artificial diet (Bower 1983) daily. For Expt 2, 18 fish were separated into 3 groups of 6 fish each and maintained and fed as above. For Expt 3, 30 fish were tagged (Floy Tag and Mfg., Inc., Seattle, WA, USA) through the dorsal musculature behind the dorsal fin and assigned to 1 of 5 groups. All fish were held at $28^{\circ} \mathrm{C}$ at 0 ppt salinity in a $1135 \mathrm{l}$ tank having undergravel filtration and fed twice daily with a commercial brand of pelleted food $\left(3 / 16^{\prime \prime}\right.$ trout feed; Zeigler Brothers, Inc., Gardener, PA, USA).

Parasite maintenance. Amyloodinium ocellatum (isolate 85-1 of DC-1) were maintained and propagated at $25^{\circ} \mathrm{C}$ using a G1B cell feeder layer as previously decribed (Noga 1987, 1989). Dinospores were harvested and used within $24 \mathrm{~h}$ of excystment. A $0.1 \mathrm{ml}$ sample of stock dinospore suspension was diluted 1:50 with IO2/HBSS and $50 \mu \mathrm{l}$ aliquots were placed in wells of a 96-well, flat-bottomed microtiter plate (Costar, Cambridge, MA, USA). Parasites were then stained with a 1:20 dilution of Lugol's Iodine in seawater, counted using an inverted microscope at $400 \times$ and expressed as the number of dinospores per ml of stock suspension. The stock suspension was diluted as necessary for serial passage of the parasite or for the various assays.

Parasite immunogen. Live dinospores excysted in IO2/HBSS were pelleted at 14000 $\times g$ for 1 min at room temperature $(21$ to $25^{\circ} \mathrm{C}$ ), resuspended in $0.5 \mathrm{ml}$ of phosphate buffered saline, pH 7.2 (PBS) and frozen at $-70^{\circ} \mathrm{C}$. When needed, the sample was thawed and sonicated (Cell Disruptor 200, mini-probe at setting \# 5; Branson Sonifjer, Danbury, CT, USA) on ice 4 times for $15 \mathrm{~s}$ each with 30 s between disruptions. Protein content of the sonicated dinospores was determined using the Coomassie Brilliant Blue G-250 Micro Assay (BioRad Laboratories, Richmond, CA, USA) according to manufacturer's directions. A suspension containing $1.0 \times 10^{5}$ dinospores $\mathrm{ml}^{-1}$ was used to intraperitoneally (IP) immunize 3 and 6 fish in Expts 1 and 2 respectively. For Expt 3, dinospores excysted in PBS were diluted in PBS to $5 \times 10^{5}$ dinospores $\mathrm{ml}^{-1}$. Half of the sample was sonicated as described before while the other half was used live, with each sample then used to inject (IP) 2 separate groups of 6 fish

Fish immunization and sample collection. Blood samples were collected from fish in each group by caudal vessel venipuncture prior to IP immunization with $0.5 \mathrm{ml}$ of the appropriate negative control, positive control, or test immunogen (lable 1). Post-immunization blood samples were obtained from fish in Expt 1 at Week 13, fish in Expt 2 every second week for 18 wk, and fish in Expt 3 at Weeks 3, 6, 9, 13, 18 and 23 . Following serum separation, an aliquot of each sample was heated to $50^{\circ} \mathrm{C}$ for $20 \mathrm{~min}$ to inactivate complement (Sakai 1981) and all sera then stored at $-70^{\circ} \mathrm{C}$

Prior to final blood collections from fish in Expt 3 at Week 23, cutaneous mucus was also collected by posteriorly wiping both flanks of the fish with a rightangled glass rod. Mucus from each fish was collected onto a clean glass plate and then aspirated into a glass test tube. A sample of each collection of mucus was placed on a slide, stained with a drop of Lugol's Iodine and examined with a light microscope for the presence of epithelial cells. Mucus samples were stored at $4{ }^{\circ} \mathrm{C}$ for $3 \mathrm{~d}$ with periodic shaking to elute proteins from the mucoid material (Ourth 1980). The material was then centrifuge at $14000 \times g$ for 2 min and the supernatant evaluated for the presence of anti-parasite antibodies by enzyme-linked immunosorbent assay (ELISA).

Cell culture infectivity assay. The cell culture infectivity assay was performed in 48-well cell culture

Table 1. Experimental parameters used for immunization studies

\begin{tabular}{cccc}
\hline $\begin{array}{c}\text { Experiment } \\
\text { no. }\end{array}$ & $\begin{array}{c}\text { No.of fish } \\
\text { per group }\end{array}$ & Weight $(\bar{x})$ & Standard length $(\bar{x})$ \\
\hline 1 & 3 & $176-218 \mathrm{~g}(196 \mathrm{~g})$ & $230-243 \mathrm{~mm}(235 \mathrm{~mm})$ \\
2 & 6 & $134-236 \mathrm{~g}(160 \mathrm{~g})$ & $160-210 \mathrm{~mm}(177 \mathrm{~mm})$ \\
3 & 6 & $205-450 \mathrm{~g}(310 \mathrm{~g})$ & $210-290 \mathrm{~mm}(253 \mathrm{~mm})$ \\
\hline
\end{tabular}

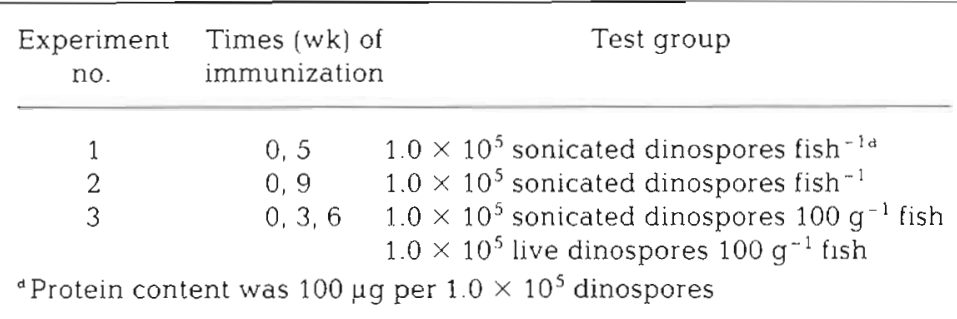


plates as previously described (Noga 1987, 1989) with the following modifications. The conditioning medium was removed by aspiration from each well and replaced with $0.4 \mathrm{ml}$ of $\mathrm{IO} 2 / \mathrm{HBSS}$ medium with the various serum dilutions to be tested and $0.1 \mathrm{ml}$ of IO2/HBSS having a known number of dinospores. The number of parasites and their stage of differentiation (i.e. trophont or 1-cell tomont, 2-cell tomont, 4-cell tomont, and 8 - or more cell tomont) were observed at 24 , 48 and $96 \mathrm{~h}$ with an inverted microscope.

ELISA. Individual and pooled sera were tested for anti-dinospore antibody by an ELISA which used antigens of the sonicated dinospore of Amyloodinium ocellatum and rabbit antiserum to affinity-purified Oreochromis aureus immunoglobulin (Smith et al. 1992). ELISA values $(E V)$ were calculated as previously described (Hornitzky \& Searson 1986, Smith et al. 1992) and $E V>2$ was considered positive (de Savigny \& Voller 1980).

Motility assay. Aliquots ( $50 \mu \mathrm{l}$ ) of serial 2 -fold serum dilutions were made in quadruplicate wells of 96 -well flat-bottom tissue culture cluster plate (Costar, Cambridge, MA, USA). Ca 200 dinospores in $50 \mu \mathrm{l}$ IO2/HBSS were then added to each well. Parasites were observed with an inverted microscope at 5, 15, $30,45,60$ and $120 \mathrm{~min}$ and subjectively scored as 0 (majority of the parasites immobilized), 1 (minimal effect, some slowing of movement and some immobilization) or 2 (no visible effect), as compared to a quadruplicate control of dinospores in IO2/HBSS. Mean values for both fresh and heat-inactivated sera were then calculated for the various serum concentrations at the different times.

Statistical analysis. The cell culture infectivity data from Expts 2 and 3 were evaluated using analysis of variance (Snedecor \& Cochran 1967). Several transformations of the data were investigated, with the mean square root producing the best approximation of normality. In the final analysis, the variables chosen were the square root of the mean number of parasites as a percentage of the same quantity for the corresponding control. Computations were performed using both the PROC UNIVARIATE and PROC GLM procedures in SAS (SAS Institute Inc., Cary, NC, USA).

\section{RESULTS}

\section{Fresh vs heat-inactivated non-immunized fish serum}

Both fresh and heat-inactivated sera from non-immunized fish were inhibitory to dinospore infectivity in the cell culture infectivity assay, with inhibition being dose-dependent (Table 2). Serum concentrations of
Table 2. Amyloodinium ocellatum. Infectivity of dinospores in various concentrations of fresh and heat-inactivated nonimmunized Oreochronis aureus serum. Values are expressed as a percentage relative to infectivity in $102 / \mathrm{HBSS}$ and are ranges for 6 experiments

\begin{tabular}{|ccc|}
\hline $\begin{array}{c}\text { Serum } \\
\text { concentration }\end{array}$ & Fresh & $\begin{array}{c}\text { Infectivity } \\
\text { Heat-inactivated }\end{array}$ \\
\hline $20.0 \%$ & 0 & 0 \\
$10.0 \%$ & $<25 \%$ & $<25 \%$ \\
$5.0 \%$ & $20-50 \%$ & $50-90 \%$ \\
$2.5 \%$ & $60-85 \%$ & $75-100 \%$ \\
$1.25 \%$ & $75-95 \%$ & $100 \%$ \\
\hline
\end{tabular}

$20 \%$ or higher completely prevented parasite infectivity, while serum at a $1.25 \%$ concentration was marginally inhibitory. Heat-inactivation of serum only partially abrogated the inhibition. The integrity of the G1B cell monolayer did not appear to be compromised at any concentration of fresh or heat-inactivated fish serum.

\section{Expt 1}

Based upon the above preliminary results, the effect of immune serum at a 5 or $2.5 \%$ concentration on dinospore infectivity and growth was examined in the infectivity assay. The $5 \%$ immune serum was more inhibitory to parasite infectivity than $5 \%$ non-immune

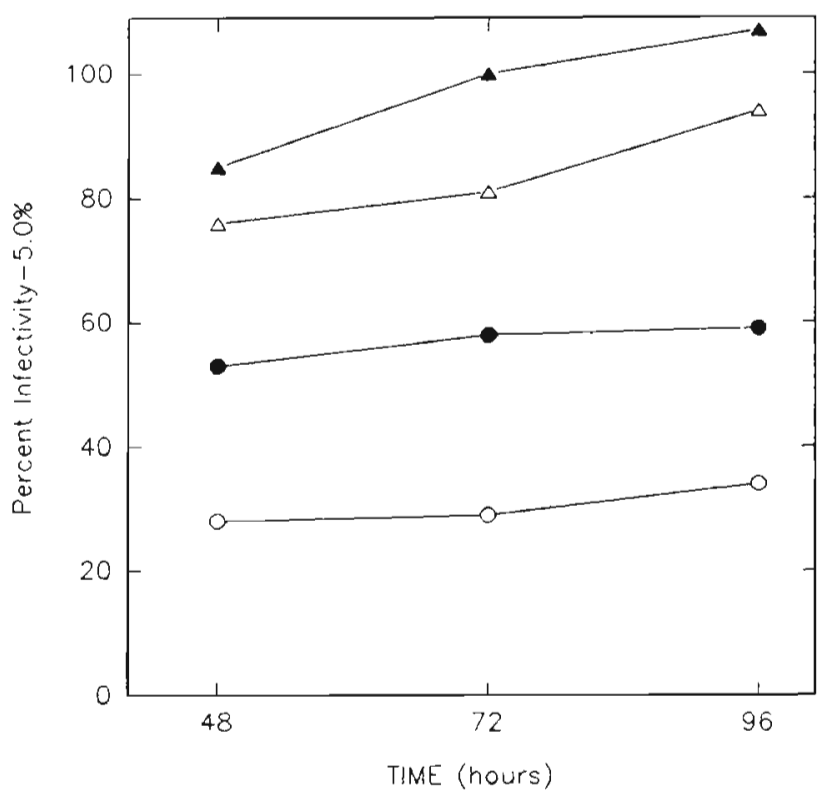

Fig. 1. Amyloodinium ocellatum. Infectivity of dinospores in immune or non-immune, fresh or heat-inactivated $5.0 \%$ serum at 48,72 and $96 \mathrm{~h}$. Values are means of individual sera expressed as a percentage relative to infectivity in control IO2/HBSS medium. (o) Fresh immune serum; (•) heatinactivated immune serum; $(\Delta)$ fresh non-immune serum; (4) heat-inactivated non-immune serum 
serum (Fig. 1). Heat-inactivation of the serum reduced the inhibition by both immune and non-immune serum. Results of parasite infectivity were similar with $2.5 \%$ serum, but differences were less pronounced.

\section{Expt 2}

The kinetics of the immune response of fish to immunization with antigens of sonicated dinospores was examined by both the infectivity assay and the ELISA. There was no significant difference in the infectivity of the parasite in immune serum compared to serum from sham-immunized fish for up to $8 \mathrm{wk}$ after a single immunization (Fig. 2). However, significantly ( $p<0.05$ ) lower infectivity oi the parasite was detected in the serum of fish immunized with the sonicated parasite within $3 \mathrm{wk}$ of the booster immunization. This was initially detected in data recorded at $96 \mathrm{~h}$ with serum collected at Week 12, but was eventually evident in data recorded at $72 \mathrm{~h}$ with serum collected at Week 14 and in data recorded at $48 \mathrm{~h}$ with serum collected at Week 16. The response persisted for the $96 \mathrm{~h}$ data until the end of the experiment at Week 18. ELISA titers mirrored the response observed in the infectivity assay, with no significant response detected until after

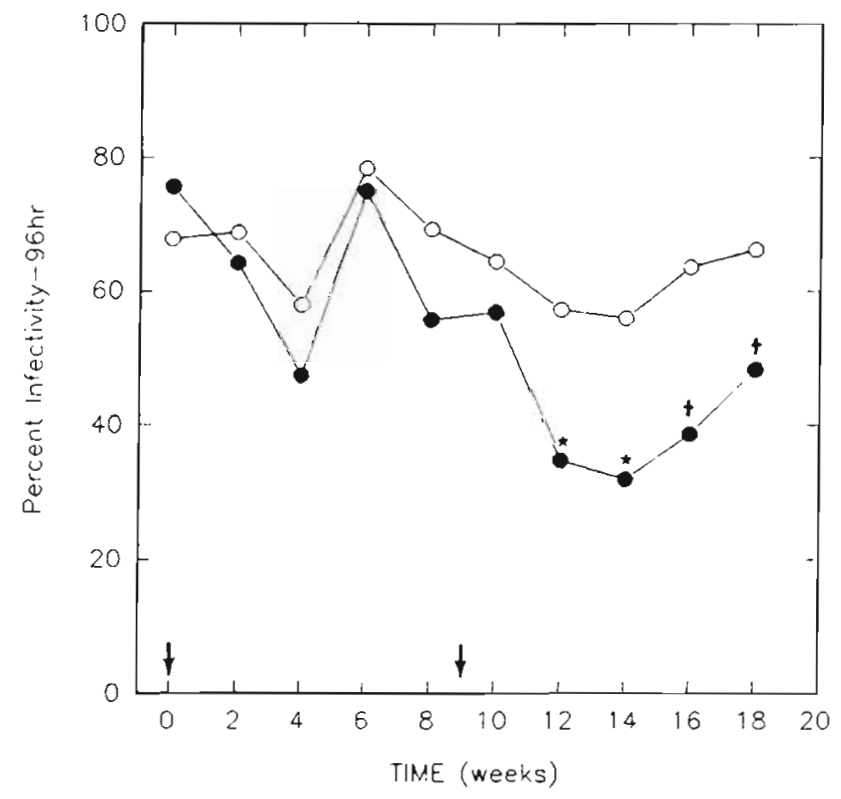

Fig. 2. Amyloodinium ocellatum. Infectivity of dinospores in heat-inactivated $5 \%$ serum at 96 h after being added to G1B cell cultures. Values are means from 6 fish group ${ }^{-1}$ and are expressed as a percentage relative to infectivity in IO2/HBSS control medium. Values significantly different from the PBS sham-immunized serum samples at the same time period: $\mathrm{p}$ $<0.05 ;+p<0.01$. Arrows: times of immunization; (0) PBS sham-immunized fish serum; ( sonicated parasite-immunized fish serum

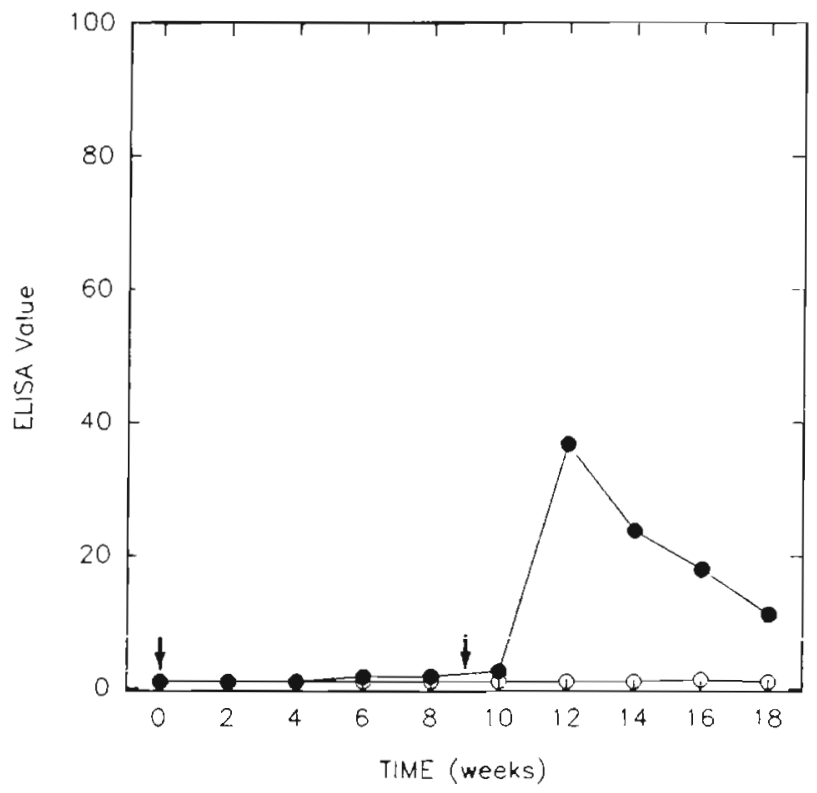

Fig. 3. Oreochromis aureus. ELISA values $(E V)$ of pooled serum from fish immunized with sonicated Amyloodinium ocellatum dinospores or sham-immunized with PBS. Arrows: times of immunization; $(O)$ serum from fish sham-immunized with PBS; (1) serum from fish immunized with sonicated dinospores

the booster immunization (Fig. 3). There was considerable variation in the response observed among individual fish in both the infectivity assay and the ELISA.

\section{Expt 3}

The kinetics and immunogenicity of antigens of sonicated dinospores compared to live organisms were then examined in both the infectivity assay and the ELISA. Significant $(p<0.01)$ inhibitory activity was detected within $3 \mathrm{wk}$ after a single immunization with live dinospores (Fig. 4). This response peaked $9 \mathrm{wk}$ post-immunization and began to decay by Week 13 , but was still significantly strong at the end of the experiment at Week 23. Response to the sonicated dinospores paralleled the live parasite immunization, but was significantly weaker. Again, the ELISA titers (Fig. 5) mirrored the response observed in the infectivity assay, with a maximum titer at Week 9 followed by a gradual decline of titers until the end of the experiment.

Heat-inactivated serum concentrations of 25 and $50 \%$ from fish sham-immunized with PBS rapidly affected the motile dinospore stage in the motility assay with immobilization of the parasite as early as 15 and 5 min respectively. Heat-inactivated serum at concentrations of $5 \%$ or lower had no visible effect on the motility of the parasite through $120 \mathrm{~min}$ (Fig 6). Although the various concentrations of serum from sham-immunized fish had some effect on dinospore 


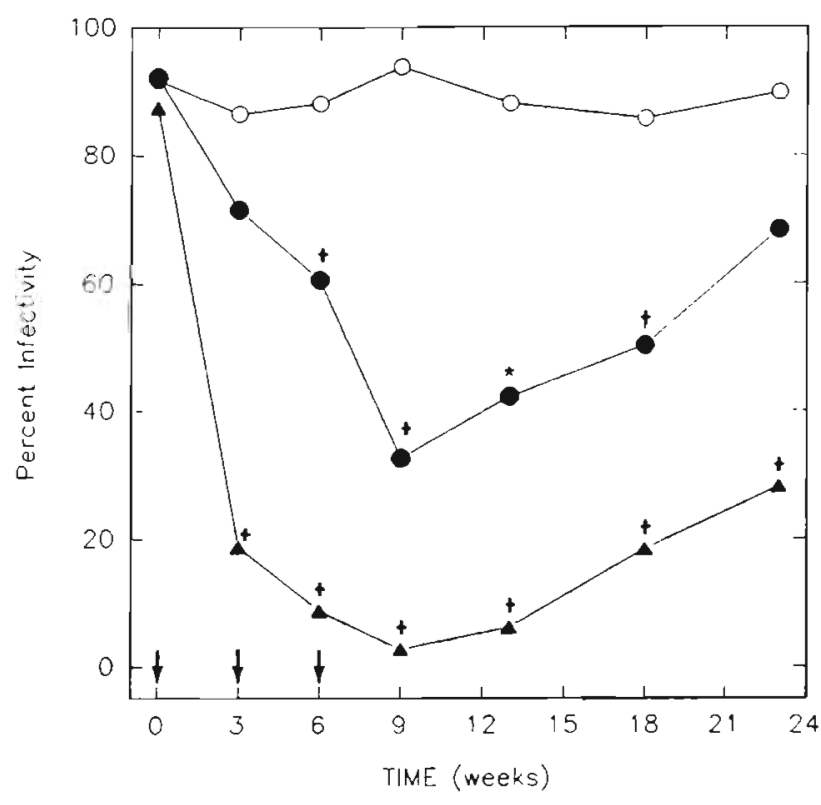

Fig. 4. Amyloodinium ocellatum. Infectivity of dinospores in heat-inactivated $5 \%$ serum at $96 \mathrm{~h}$ after being added to G1B cell cultures. Values are means from pooled sera $(6$ fish group ${ }^{-1}$ ) and are expressed as a percentage relative to infectivity in IO2/HBSS. Values significantly different from sera of PBS sham-immunized fish at the same time period: $\star p<0.05$; $+p<0.01$. All values from sera of fish immunized with live dinospores were significantly different $(p<0.01)$ at all times from values from sera of fish immunized with sonicated dinospores. Arrows: times of immunizations; (O) PBS sham-immunized fish serum; (1) sonicated parasite-immunized fish serum: $(\mathbf{\Delta})$ live parasite-immunized fish serum

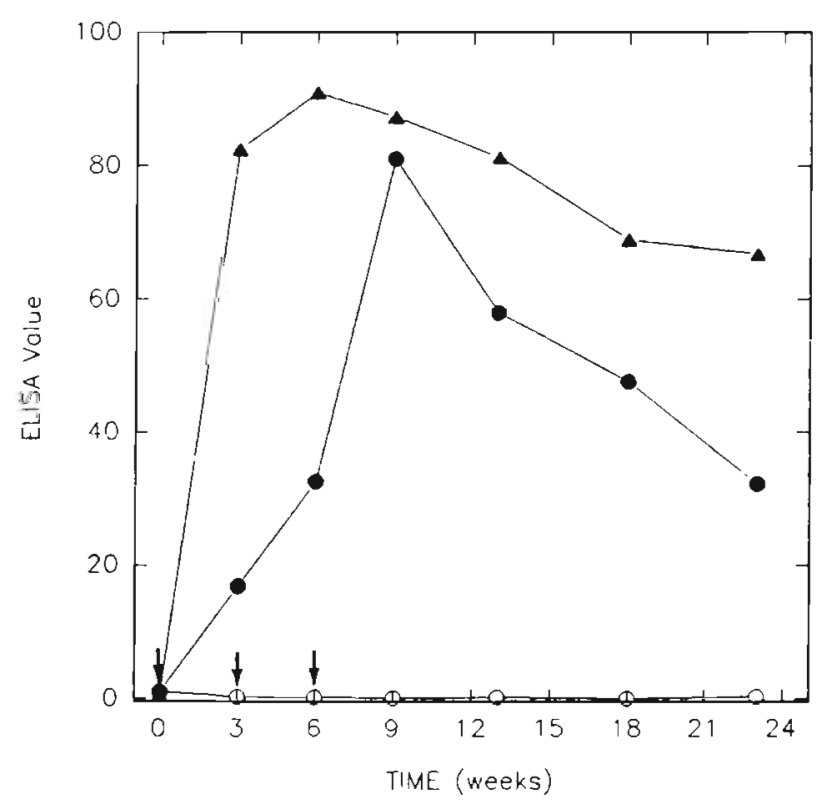

Fig. 5. Oreochromis aureus. ELISA values (EV) of pooled sera from fish immunized with either PBS, sonicated dinospores or live dinospores. Arrows: times of immunization; (O) PBS sham-immunized fish serum; (1) sonicated parasite-immunized fish serum; (A) live parasite-immunized fish serum

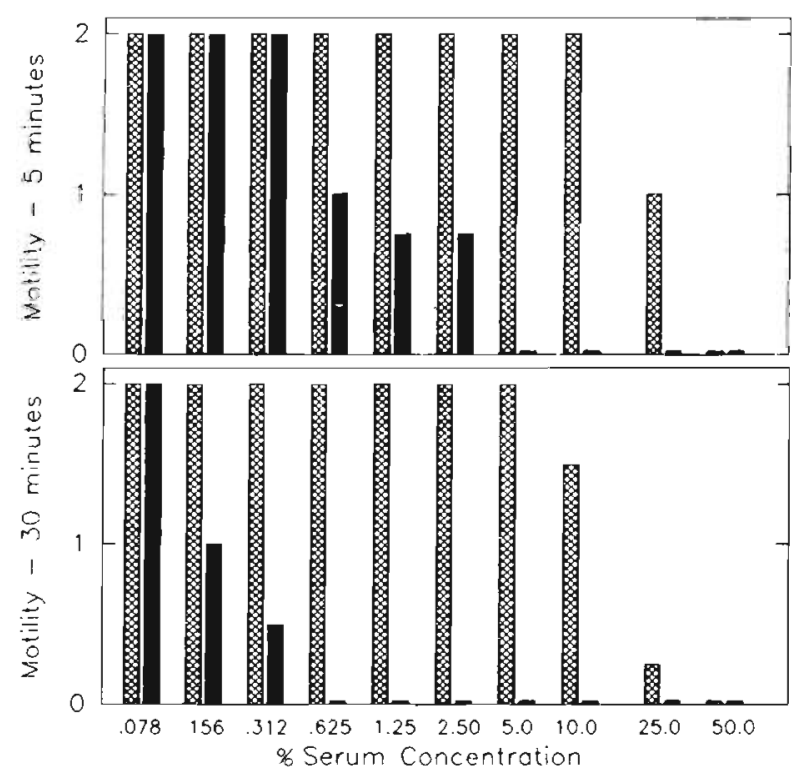

Fig. 6. Amyloodinium ocellatum. Motility assay of dinospores at 5 and $30 \mathrm{~min}$ in immune or non-immune heat-inactivated serum concentrtions. Cross-hatched bars: serum from fish sham-immunized with PBS; solid bars: serum from fish immunized with live dinospores

motility, agglutination activity was not observed. By comparison, heat-inactivated serum concentrations of $5 \%$ and above from fish immunized with the live parasites immobilized all dinospores within $5 \mathrm{~min}$. Complete immobilization of dinospores occurred by 15 min in the $1.25 \%$ serum, by $30 \mathrm{~min}$ in the $0.625 \%$ serum, by $60 \mathrm{~min}$ at the $0.312 \%$ serum and by $120 \mathrm{~min}$ at the $0.156 \%$ serum concentration. Parasite agglutination occurred in heat-inactivated immune serum at concentrations between 2.5 and $0.156 \%$. Fresh serum from both groups of fish had similar effects as their heat-inactivated counterpart, except that detectable

Table 3. Oreochromis aureus. Anti-dinospore antibody titers in mucus of fish in Expt 3 immunized with either live Amyloodinium ocellatum dinospores, sonicated dinospores or sham-immunized with PBS. Fish were immunized and boosted at Weeks 0,3 and 6 and samples of mucus and blood were collected $12 \mathrm{wk}$ after the third immunization (Week 23 of experiment

\begin{tabular}{|c|c|c|c|c|}
\hline \multirow{2}{*}{ Treatment } & \multirow{2}{*}{ Fish no. } & \multicolumn{3}{|c|}{ ELISA Value } \\
\hline & & $\begin{array}{c}\text { Serum } \\
1: 1000 \\
\text { dilution }\end{array}$ & $\begin{array}{c}\text { Mucus } \\
1: 100 \\
\text { dilution }\end{array}$ & $\begin{array}{c}\text { Mucus } \\
\text { 1:1000 } \\
\text { dilution }\end{array}$ \\
\hline Dinospores-live & 811 & 22.5 & $<1$ & $<1$ \\
\hline Dinospores-live & 840 & 26.9 & $<1$ & $<1$ \\
\hline Dinospores-live & 831 & 67.6 & 18.3 & 2.4 \\
\hline PBS & 809 & $<1$ & $<1$ & $<1$ \\
\hline PBS & 812 & $<1$ & $<1$ & $<1$ \\
\hline PBS & 836 & $<1$ & $<1$ & $<1$ \\
\hline
\end{tabular}


effects on the dinospores were observed earlier when fresh serum was used.

Samples of cutaneous mucus collected from fish sham-immunized with PBS or immunized with live parasites were examined by light microscopy and the ELISA. Epithelial cells were not detected in any of the iodine-stained mucus samples collected from the fish. By the ELISA, none of the 3 PBS sham-immunized fish had detectable antibody to antigens of the sonicated dinospores (Table 3). However, anti-dinospore antibody was detected by the ELISA in mucus of 1 of the 3 fish immunized with live dinospores.

\section{DISCUSSION}

The primary purpose of this study was to determine if fish immunized with dinospores of Amyloodinium ocellatum developed a specific humoral immune response to the parasite. An ELISA that detected specific antibody to antigens of the parasite permitted the evaluation and quantification of the effect of parasite immunization on the fish. A culture system allowing continuous in vitro growth of the parasite facilitated both the production of large numbers of parasites needed for immunization of fish and the observation of the effects of immune serum factors on the parasite. The parasite in the culture system is very similar cytopathologically and developmentally to the parasite as found in natural infections (Noga 1989). Therefore, modifications to the culture system allowed the evaluation and quantification of the effect of immune and non-immune serum on the infectivity and growth of the parasite in vitro. Parasite infectivity of experimental groups were compared as a ratio to parasite infectivity in culture medium without serum to help eliminate any variation that might have occurred in parasite growth.

The results of this investigation demonstrate that fish develop a titratable, specific immune response to immunization with antigens of the dinospore of Amyloodinium ocellatum. This response was detected with all 3 assays employed, including an antibody-detecting ELISA, a modified cell culture infectivity assay, and a dinospore motility assay. The ELISA, as an objective rather than a subjective test, was most useful in the quantification of the immune response.

An additional goal of this study was to determine the optimal conditions for measuring the biological activity of the specific humoral response to Amyloodinium ocellatum dinospore antigens using these tests. In developing the assys, it was discovered that non-immune tilapia serum had a considerable inhibitory effect upon dinospore infectivity. Significant parasite inhibition was detected in as low as $1.25 \%$ fresh non-immune serum (Table 2). Heating the serum to inactivate com- plement reduced, but did not eliminate, the inhibitory effect, suggesting that complement-activated or other heat-sensitive serum factors have antiparasitic activity against $A$. ocellatum. The potential importance of complement was also demonstrated in the infectivity assay by the greater activity of fresh immune serum compared to heat-inactivated immune serum (Fig. 1).

Based upon these preliminary results, heat-inactivated serum at a $5 \%$ concentration was chosen for comparing immune with non-immune sera, since this concentration appeared to have the greatest sensitivity for detecting a specific response. Heat-inactivation of the serum also allowed the study to focus on the antibody response without the potential immuno-potentiating effect of complement. Since the sensitivity of the infeciivily assay with fishin seruinn was found to increase with time in the system, $96 \mathrm{~h}$ was chosen as the optimal time for measuring the response. Incubation times longer than $96 \mathrm{~h}$ became less accurate because a new generation of dinospores began to excyst from the tomonts and reinfect the monolayer. Immune serum not only inhibited dinospore infectivity, but also slowed the growth and differentiation of the parasite. This was especially evident with immune serum from fish immunized with live dinospore, where in some cases, almost all parasites were arrested in the trophont or tomont stage. The relevance of this result to in vivo protection must await further studies which examine parasites that have been exposed to immune serum and then incubated in serum-free culture conditions, but such a residual effect of immune serum on the parasite may be an important mechanism in protection of host populations.

The infectivity assay was useful in ascertaining the possible biological relevance of the other assays. For example, the results of the ELISA were closely correlated with the results of the infectivity assay, strongly suggesting that the inhibitory response observed in the infectivity assay induced by serum from fish vaccinated with dinospores of the parasite was due to the specific anti-dinospore antibodies detected by the ELISA.

The dinospore motility assay provided evidence that both immobilization and agglutinating antibodies may be involved in the protective response, both of which are important responses of parasitic protozoa to immune serum (Preer 1986). Hines \& Spira (1974) found that serum from carp Cyprinus carpio that had acquired immunity to Ichthyophthirius multifilis immobilized the trophozoites. Clark et al. $(1987,1988)$ and Dickerson et al. (1989) found that serum from channel catfish immune to I. multifilis agglutinated the tomites at high (1:32) serum concentrations and killed them at low $11: 28)$ concentrations. Similar to the results of Clark et al. (1987), heat-inactivation of immune serum 
in the present study had no effect upon its ability to agglutinate parasites, although immobilization was much faster in fresh serum. Thus, agglutination does not appear to be complement-mediated, but as was demonstrated with the infectivity assay, potent inhibitory effects are present in fresh serum.

Serum is the origin of many biologically protective substances and has been shown to harbor important specific defensive factors against other fish ectoparasites (Meyers et al. 1980, Goven et. al. 1980a, b, 1981, Woo 1981, Clark et al. 1987). Serum also has the advantage of being relatively easy to quantify compared to cutaneous mucus, which due to its physical properties and external location, is difficult to mainipulate. However, the cutaneous mucus layer forms the first line of defense against ectoparasites and thus it was important to examine mucus of immunized fish for anti-dinospore activity. One of the major concerns in examining the mucus was the possible contamination of samples by serum during collection. Being an unkeratinized epithelium, fish skin is highly susceptible to trauma. In order to reduce potential injury to the skin, mucus samples were collected with a smooth glass rod. The absence of any epithelial cells in stained wet mounts of these samples indicated that this technique was relatively nontraumatic. Others have used methods that may have been more traumatic, including wooden tongue blades (Ourth 1980), filter paper (Bradshaw et al. 1971) and cotton-tipped applicator sticks (St. Louis-Cormier et al. 1984). Since these investigators did not examine mucus samples for epithelial cells, it cannot be determined whether serum contamination may have influenced their results.

Anit-dinospore activity was detected in the mucus of 1 of 3 parasite-immunized fish. While these studies were very limited, they do suggest that tilapia may have protective antibody in the cutaneous mucus. Whether this is produced and secreted by the skin or derived from serum remains to be determined. The activity measured was considerably lower than that present in serum, but, for reasons previously stated, serum levels cannot be quantitatively compared to mucus activity. Further, all activity in the mucus may not have been measured if the extraction technique was inadequate. The kinetics of the immune response in the mucus also may not follow that of serum. Thus, mucus samples may not have been collected at the optimal time post-immunization to detect antibody to Amyloodinium ocellatum. In addition, antibody titers in mucus may not be as high as those found in the serum. Numerous studies have compared the different routes of antigen administration on antibody response (Snieszko 1970, Gould et al. 1978, Anderson et al. 1983, Horne et al. 1984, Pyle \& Dawe 1985, Ellis 1988), and most have generally concluded that parenteral im- munization provides high antibody titers in the serum of fish, but not necessarily high antibody titers in the mucus. However, these findings support the results of other investigators reporting evidence of a secretory immune response in fish (Ourth 1980, Lobb \& Clem 1981, St. Louis-Cormier et al. 1984, Lobb 1987). Considering the immunopotentiating effect of complement in the piscine immune system, only a minute amount of antibody may need to be present in order to activate a protective immune response. This is further supported by the data from the motility assay showing that serum which was not heat-inactivated immobilized the parasite more rapidly than serum at the same concentration which was heat-inactivated.

Although the results cannot be compared among experiments because of different experimental conditions, the results clearly indicate that immunization of fish with live dinospores produces a stronger immune response than immunization with sonicated dinospores. This suggests either that sonication of the parasite alters the antigens of the parasite in such a way as to make it less immunogenic, or that the fish respond better immunologically to the living organism. One explanation for this may be that sonication of the parasite may have disrupted the sequence of epitopes needed by the fish to respond properly to the parasite. Another possibility is that the live parasite may survive for a period of time in the peritoneal cavity of the fish after immunization, as shown for Ichthyophthirius multifiliis (Dickerson et al. 1985), resulting in prolonged stimulation of the immune system of the host.

Acknowledgements. This research was supported by grant \# US-1341-87 from the United States-Israel Binational Agricultural Research and Development Fund. The authors acknowledge the technical assistance of Dave Fisher and Bill King, and computer and graphics assistance of Cynthia Babineau.

\section{LITERATURE CITED}

Anderson, D. P., Merchant, B., Dixon, O. W., Schott, C. F. Lizzio, E. F. (1983). Flush exposure and injection immunization of rainbow trout to selected DNP (dinitrophenyl) conjugates. Dev. comp. Immunol. 7: 261-268

Bower, C. E. (1983). The basic marine aquarium. Charles C. Thomas, Springfield, p. 192-195

Bradshaw, C. M., Richard, A. S., Sigel, M. M. (1971). IgM antibodies in fish mucus. Proc. Soc. exp. Biol. Med. 136 $1122-1124$

Brown, E. M. (1931). Note on a new species of dinoflagellate from the gills and epidermis of marine fish. Proc. zool. Soc. Lond. 1: 345-346

Brown, E. M. (1934). On Oodinium ocellatum Brown, a parasitic dinoflagellate causing epidemic disease in marine fish. Proc. zool. Soc. Lond., 1. 583-607

Brown, E. M., Hovasse, R. (1946). Amyloodinium ocellatum (Brown), a peridinian parasitic on marine fishes. A complementary study. Proc. Zool. Soc. London 116(1): 33-46

Clark, T G., Dickerson, H. W., Findly, R. G. (1988). Immune 
response of channel catfish to ciliary antigens of Ichthyophthirius multifilis. Dev. comp. Immunol. 12: $581-594$

Clark, T G., Dickerson, H. W., Gratzek, J.B., Findly R. C. (1987). In vitro response of Ichthyophthirius multifilis to sera from immune channel catfish. J. Fish Biol. 31A: 203-208

de Savigny, D., Voller, A. (1980). The communication of quantitative ELISA results. In: Malvano, R. (ed.) Immunoenzymatic assay techniques. Developments in clinical biochemistry, Vol. I. Martinus Nighoff Publ., The Hague, p. 272

Dickerson, H. W. Clark, T. G., Findly, R. C. (1989). Ichthyophthirius multifiliis has membrane-associated immobilization antigens. J. Protozool. 36: 159-164

Dickerson, H. W., Lohr, A. L., Gratzek, J. B. (1985). Experimental intraperitoneal infection of channel catfish, Ictalurus punctatus (Rafinesque), with Ichthyophthirius multifiliis (Fouquet). J. Fish Dis 8: 139-142

Dempster, R. P. (1955). The use of copper sulfate as a cure for fish disease caused by parasitic dinoflagellates of the genus Oodinium. Zoologica 40: 133-138

Ellis, A. E. (1988). Current aspects of fish vaccination. Dis. aquat. Org. 4: $159-164$

Ghittino, P., Bignani, S., Annibali, A., Boni, L. (1980). First record of serious oodiniasis in sea bass (Dicentrarchus la. brax) intensively reared in brackish water. Riv. ital. Piscic. Ittiopat. 15: 122-127

Gould, R. W., O'Leary, P. J., Garrison, R. L., Rohovec, J. S., Fryer, J. L. (1978). Spray vaccination: a method for the immunization of fish. Fish Path. 13: 63-68

Goven, B. A., Dawe, D. L., Gratzek, J. B. (1980a). Antiprotozoal immunization studies in the channel catfish, Ictalurus punctatus. Proc. WId Maricult. Soc. 11:271-274

Goven, B. A., Dawe, D. L., Gratzek, J. B. (1980b). Protection of channel catfish, Ictalurus punctatus Rafinesque, against Ichthyophthirius multifiliis Fouquet by immunization. J. Fish Biol. 17: 31.1-316

Goven, B. A., Dawe, D. L., Gratzek, J. B. (1981). In vitro demonstration of serological cross-reactivity between Ichthyophthirius multifiliis (Fouquet) and Tetrahymena pyriformis (Lwoff). Dev. comp. Immunol. 5: 283-289

Hines, R. S., Spira, D. T (1974). Ichthyophthiriasis in the minor carp Cyprinus carpio (L.) V. Acquired immunity. J. Fish Biol. 6: 373-378

Horne, M. T., Tatner, M. F., Ward, P. D. (1984). Vaccination of fish: a practical view. Vet. Rec. 114: 537-539

Hornitzky, M., Searson, J. (1986). The relationship between the isolation of Brucella abortus and serological status of infected, non-vaccinated cattle. Aust. vet. J. 63: 172-174

Laird, M. (1956). Aspects of fish parasitology. Proc. 2nd Joint Symposium of the Science Society of Malaya and Malayan Mathematical Society, p. 46-54

Lawler, A. R. (1977a). Dinoflagellate (Amyloodinium) infestation of pompano. In: Disease diagnosis and control in North American marine aquaculture. Sindermann, C. J. (ed.) Elsevier Scientific, Amsterdam, p. 257-264

Lawler, A. R. (1977b). The parasitic dinoflagellate Amyloodinium ocellatum in marine aquaria. Drum and Croaker 17 : $17-20$

Lawler, A. R. (1979). North American fishes reported as hosts of Amyloodinium ocellatum (Brown, 1931). Drum and Croaker 19: 8-14

Lawler, A. R. (1980). Studies on Amyloodinium ocellatum (Dinoflagellata) in Mississippi Sound: natural and experi-

Responsible Subject Editor: D. E. Hinton, Davis, California, USA mental hosts. Gulf Res. Rep. 6: 403-413

Lobb, C. J. (1987). Secretory immunity induced in catfish, Ictalurus punctatus, following bath immunization. Dev. comp. Immunol. $11727-738$

Lobb, C. J., Clem, L. W. (1981). Phylogeny of immunglobulin structure and function. XI. Secretory immunoglobulins in the cutaneous mucus of the sheepshead, Archosargus probatocephalus. Dev. comp. Immunol. 5: 587-596

Meyers, T R., Millemann, R. E., Fustish, C. A. (1980). Glochidiosis of salmonid fishes. IV. Humoral and tissues responses of coho and chinook salmon to experimental infection with Margaritifera margaritifera (L.) (Pelecypoda: Margaritanidae). J. Parasit. 66: 274-281

Nigrelli, R. F. (1936). The morphology, cytology and life history of Oodinium ocellatum Brown, a dinoflagellate parasite on marine fishes. Zoologica 21: 129-164

Nigrelli, R. F. (1940). Mortality statistics for specimens in the New York Aquarium, 1939. Zoologica 25: 525-552

Nogá, E. J. (1387). Fropagation in cell culture of the diñoflay. ellate Amyloodinium, an ectoparasite of marine fishes. Science 236: 1302-1304

Noga, E. J. (1989). Culture conditions affecting the in vitro propagation of Amyloodinium ocellatum. Dis. aquat. Org. 6: $137-143$

Ourth, D. D. (1980). Secretory IgM, lysozyme and lymphocytes in the skin mucus of the channel catfish, Ictalurus punctatus. Dev. comp. Immunol. 4: 65-74

Paperna, I. (1980). Amyloodinium ocellatum (Brown, 1931) (Dinoflagellida) infestations in cultured marine fish at Eilat, Red Sea: epizootiology and pathology. J. Fish Biol. 3: 363-372

Paperna, I., Baudin Laurencin, F. (1979). Parasitic infections of sea bream, Sparus aurata, in mariculture facilities in France. Aquaculture 16: 173-175

Preer, J. R. (1986). Surface antigens of Paramecium. In: Gall J. G. (ed.) The molecular biology of protozoa. Academic Press, London, p. 301-339

Pyle, S. W., Dawe, D. L. (1985). Immune response of channel catfish, Ictalurus punctatus Rafinesque, to bacterial and protozoal antigens administered by three routes. Aquaculture 46: $1-10$

Sakai, D. K. (1981). Heat inactivation of complement and immune hemolysis reactions in rainbow trout, masu salmon, coho salmon, goldfish and tilapia. Bull. Jap. Soc. scient. Fish. 47: 565-571

Sindermann, C. F. (1990). Principle diseases of marine fish and shellfish, 2nd edn. Vol. 1, Diseases of marine fish. Academic Press, San Diego, p. 259-277

Smith, S. A., Levy, M. G., Noga, E. J. (1992). Development of an enzyme-linked immunosorbent assay (ELISA) for the detection of antibody to the parasitic dinoflagellate Amy. loodinium ocellatum in Oreochromis aureus. Vet. Parasit. 42: $145-155$

Snedecor, G. W., Cochran, W. C. (1967). Statistical methods, 6 th edn. Iowa State Univ. Press, Ames

Snieszko, S. F. (1970). Immunization of fishes: a review. J. Wildl. Dis. 6: 24-30

St. Louis-Cormier, E. A., Osterland, C. K., Anderson, P. D. (1984). Evidence for a cutaneous secretory immune system in rainbow trout (Salmo gairdneri). Dev comp. Immunol. 8: $71-80$

Woo, P. T. K. (1981). Acquired immunity against Trypanosoma danilewskyi in goldfish, Carassius auratus). Parasitology 83: $343-34$

Manuscript first received: November 12, 1990

Revised version accepted: September 16, 1992 